\title{
Armia Ukraińskiej Republiki Ludowej w 1920 r.
}

Андрій О. Руккас, «Разом з польським військом»: Армія Украӥнської Народної Республіки 1920 р. (структура, організація, чисельність та уніформа), Ніжин 2013, ss. 480.

$\mathrm{P}$ od koniec 2013 r., w Nieżynie ukazała się książka kijowskiego historyka Andrija Rukkasa poświęcona Armii Ukraińskiej Republiki Ludowej w 1920 r. W tytule autor wyraźnie określił, że przedmiotem pracy są problemy związane ze strukturą, organizacją, liczebnością i umundurowaniem wojsk ukraińskich w okresie ich sojuszu z Wojskiem Polskim. Mimo że od wydarzeń tych minęło ponad dziewięćdziesiąt lat, to dotycząca ich historiografia, zarówno ukraińska, jak i polska, nadal wykazuje wiele braków. Także tematyka podjęta przez A. Rukkasa nie doczekała się jak dotąd całościowego naukowego opracowania.

W latach 1917-1920 Ukraińcy podjęli działania mające na celu uzyskanie niepodległości. Powstawały wówczas ukraińskie organizmy państwowe, które zmuszone były walczyć o swoją niepodległość. Dlatego też kluczowym zagadnieniem dla ówczesnych ukraińskich przywódców były problemy związane z tworzeniem i funkcjonowaniem sił zbrojnych. Reaktywowana pod koniec 1918 r., po upadku rządów hetmana Pawły Skoropadskiego, Ukraińska Republika Ludowa (URL) przez cały rok 1919 zmagała się z bolszewikami, a następnie także z Siłami Zbrojnymi Południa Rosji. Zacięte walki, trudne położenie materialne oraz epidemie chorób zakaźnych sprawiły, że pod koniec 1919 r. zdziesiątkowana Armia URL straciła zdolność bojową. W tej sytuacji jedynym wyjściem dla Ukraińców wydawało się porozumienie z Polską. Obie strony musiały się wówczas zmagać z tym samym wrogiem - bolszewikami. Po tzw. katastrofie lubarskiej przywódca URL, Główny Ataman Symon Petlura udał się do Warszawy, aby osobiście prowadzić rozpoczęte już wcześniej negocjacje. Ostatecznie zakończyły się one podpisaniem 21 kwietnia 1920 r. polsko-ukraińskiego sojuszu politycznego, a kilka dni później 
także konwencji wojskowej. W dniu 25 kwietnia 1920 r. rozpoczęła się wspólna, polsko-ukraińska ofensywa znana jako ,wyprawa kijowska”. Wtedy to przywódcy połączonych sojuszem państw - Józef Piłsudski i Symon Petlura - wydali do ludności Ukrainy odezwy thumaczące przyczyny i cele wspólnych działan zbrojnych. Józef Piłsudski w swojej odezwie pisał: „Razem z wojskami polskimi wracają na Ukrainę szeregi walecznych jej synów [...]"1. To właśnie do tego fragmentu nawiązuje tytuł książki A. Rukkasa.

Kampania 1920 r. była ostatnią, jaką odbyły regularne siły zbrojne Ukraińskiej Republiki Ludowej. Ukraińcom nie było dane wywalczenie niepodległości. Przy polskiej pomocy udało im się jednak stworzyć wówczas stosunkowo silną i dobrze zorganizowaną armię, która była najważniejszym sojusznikiem Wojska Polskiego podczas wojny $\mathrm{z}$ bolszewikami.

Problematyka sojuszu polsko-ukraińskiego budziła zainteresowanie badaczy już w okresie międzywojennym. Prace na ten temat publikowali zarówno historycy polscy, jak i przebywający na emigracji historycy ukraińscy. Na Ukrainie sowieckiej problematyka ta została skazana na zapomnienie, a nieliczne prace miały charakter czysto propagandowy. Po drugiej wojnie światowej także w Polsce dziejom wojny polsko-bolszewickiej, a co za tym idzie również sojuszu polsko-ukraińskiego poświęcono tylko pojedyncze i nacechowane ideologicznie opracowania. Dopiero w latach 90-tych, po przemianach politycznych w Polsce i ogłoszeniu niepodległości przez Ukrainę, badania wspomnianej tematyki ruszyły naprzód. W Polsce ukazało się kilka interesujących monografii ${ }^{2}$, a na Ukrainie licznie przedrukowywano prace historyków emigracyjnych, wydawano dokumenty i wspomnienia ${ }^{3}$. Jednak autorzy publikacji skupiali się przede wszystkim na kwestiach politycznych, stosunkowo pobieżnie traktując problematyką militarną. Nie znaczy to, że dzieje Armii URL pozostają nieznane. Zarówno w Polsce, jak i na Ukrainie ukazało się kilka prac mających fundamentalne znaczenie dla historii ukraiń-

${ }^{1}$ Odezwa Józefa Pitsudskiego do mieszkańców Ukrainy, 26 kwietnia 1920, [in:] Sasiedzi wobec wojny 1920 roku. Wybór dokumentów, oprac. J. Cisek, Londyn 1990, s. 170-171.

2 Zob. choćby: Z. Karpus, Jeńcy i internowani rosyjscy i ukraińscy $w$ Polsce $w$ latach 1918-1924, Torun 1991; Polska i Ukraina. Sojusz 1920 roku i jego następstwa, red. Z. Karpus, W. Rezmer, E. Wiszka, Torun 1997; J. J. Bruski, Petlurowcy. Centrum Państwowe Ukraińskiej Republiki Ludowej na wychodźstwie (1919-1924), Kraków 2000; J. Pisuliński, Nie tylko Petlura. Kwestia ukraińska w polskiej polityce zagranicznej w latach 1918-1939, Wrocław 2004.

3 Zob. choćby: В. Верига, Визвольні змагання в Україні 1914-1923, Львів 1998; I. Мазепа, Украӥна в огні й бурі револючії 1917-1921, Київ 2003; Директорія, Рада Народних Міністрів Української Народної Республіки 1918-1920. Документи і матеріали у 2 томах, ред. В. Верстюк, Київ 2006; Симон Петлюра. Статті-листи - документи, т. IV, ред. В. Сергійчук, Київ 2006; М. Омелянович-Павленко, Спогади командарма (1917-1920), упор. М. Ковальчук, Київ 2007. 
skich sił zbrojnych w $1920 \mathrm{r}^{4}$ Stwierdzić jednak należy, że żadna z nich nie może pretendować do miana wyczerpującej, opartej na całym dostępnym materiale źródłowym monografii, ukazującej organizacyjne problemy Armii Ukraińskiej Republiki Ludowej. Wydaje się, że dopiero opracowanie Andrija Rukkasa wypełnia tę istotną lukę w historiografii.

Omawiana praca powstała na podstawie bardzo szerokiej kwerendy archiwalnej. W zakresie wykorzystania dostępnych źródeł trudno cokolwiek zarzucić autorowi. Skrupulatne badania zostały przeprowadzone przede wszystkim w dwóch instytucjach przechowujących największą ilość zespołów akt wytworzony przez ukraińskie siły zbrojne w 1920 r.: w Centralnym Państwowym Archiwum Wyższych Organów Władzy i Administracji Ukrainy w Kijowie (Центральний державний архів вищих органів влади та управління України) oraz w Centralnym Archiwum Wojskowym w Warszawie (zespół akt Sprzymierzona Armia Ukraińska 1918-1939). Poza tym A. Rukkas wykonał kwerendy uzupełniające w zbiorach archiwalnych Biblioteki Narodowej w Warszawie oraz Instytutu Józefa Piłsudskiego w Ameryce.

Książka A. Rukkasa jest specyficzna, ponieważ poza dwoma pierwszymi rozdziałami pozostałe mają charakter informacyjno-encyklopedyczny. Treść ta jest jednak niezwykle dokładna, wyczerpująca oraz poparta licznymi odwołaniami do źródeł. Sam autor we wstępie napisał, że jego celem było „stworzyć »suchą" i lakoniczną pracę o charakterze naukowym, maksymalnie nasyconą materiałem faktograficznym, opartą przeważnie na materiałach archiwalnych. Zawiera ona przede wszystkim informacje dotyczące formowania centralnych organów dowodzenia, rodzajów wojsk i służb, związków taktycznych, oddziałów, samodzielnych pododdziałów i instytucji; ich struktury organizacyjnej, liczebności, kadry dowódczej" [tłumaczenie M. K.] $]^{5}$. W ten sposób czytelnik otrzymał opracowanie w zasadzie pozbawione ocen czy wartościowania, jednak nasycone informacjami pozwalającymi samodzielnie wyrobić sobie zdanie na temat stanu Armii URL w $1920 \mathrm{r}$.

4 Spośród prac polskich historyków szczególną uwagę poświęcić należy pionierskiej pracy Zbigniewa Karpusa, Wschodni sojusznicy Polski w wojnie 1920 roku. Oddziaty wojskowe ukrainskie, rosyjskie, kozackie i białoruskie w Polsce w latach 1919-1920, Toruń 1999. Poza tym zob. choćby: О. Удовиченко, Україна у війні за державність, Київ 1995; J. Legieć, Armia Ukraińskiej Republiki Ludowej w wojnie polsko-ukraińsko-bolszewickiej w 1920 r., Toruń 2002; Я. Тинченко, Офіиерский корпус Армї̈ Украӥнської Народної Республіки (1917-1921), Книга 1, Київ 2007, Книга 2, Київ 2011; G. Skrukwa, Formacje wojskowe ukraińskiej ,,rewolucji narodowej” 1914-1921, Toruń 2008; E. Wiszka, Szósta Siczowa Dywizja Strzelecka Armii Ukraińskiej Republiki Ludowej. Formowanie, szlak bojowy, internowanie 1920-1924, Toruń 2012.

5 А. Руккас, «Разом з польським військом»: Армія Украӥнської Народної Республіки 1920 р. (структура, організачія, чисельність та уніформа), Ніжин 2013, s. 6. 
Omawiana praca składa się ze wstępu, osiemnastu rozdziałów i zakończenia. Pewien niedosyt budzi u czytelnika wstęp. Jest on bardzo krótki (1,5 strony) i oprócz określenia i uzasadnienia podjętego tematu, zawiera jedynie deklaracje autora co do celu, jaki przyświecał mu przy pisaniu rozprawy oraz drobne, choć ciekawe, uwagi terminologiczne. Szkoda, że nie uwzględniono tu charakterystyki wykorzystanych opracowań, a tym bardziej źródeł. Dla czytelnika ciekawe mogłyby być informacje o stanie ich zachowania, strukturze i miejscach przechowywania.

Obszerne pierwsze dwa rozdziały maję charakter wprowadzający do zasadniczej części pracy. Liczący ponad 30 stron rozdział pierwszy opisuje genezę sojuszu polsko-ukraińskiego z 1920 r. Autor dokładnie przedstawił skomplikowany i trudny proces osiągania kompromisu, który ostatecznie zaowocował podpisaniem umowy politycznej i wojskowej. Znacznie obszerniejszy (prawie 90 stron) rozdział drugi poświęcony jest historii wspólnych, polsko-ukraińskich, działań bojowych przeciwko bolszewikom w kampanii 1920 roku.

Pozostałe szesnaście rozdziałów to w zamyśle autora zasadnicza część opracowania. W sumie rozdziały te liczą ponad 300 stron, a każdy z nich opisuje określone instytucje wojskowe, rodzaje wojsk, służby, poszczególne związki taktyczne i oddziały. Rozdział trzeci poświęcony jest naczelnym władzom wojskowym, dowództwom i instytucjom centralnym Armii URL. W kolejnych dziewięciu rozdziałach autor przedstawił kolejno: piechotę, kawalerię, artylerię, wojska techniczne, lotnictwo, oddziały rezerwowe, żandarmerię, organizację zaplecza i oddziały etapowe oraz służby. Rozdział trzynasty opisuje Kamieniecką Pieszą Szkołę Junacką (szkoła oficerska), czternasty poświęcony jest ukraińskiej flocie wojennej, a piętnasty przedstawia Samodzielny Korpus Ochrony Granic. Pozostałe dwa rozdziały dotyczą oddziałów kozackich formowanych w ramach ukraińskich sił zbrojnych oraz wspólnych oddziałów polsko-ukraińskich. Ostatni, osiemnasty rozdział, wyjaśnia kwestie związane ze stosowanymi w Armii URL stopniami wojskowymi i służbowymi, oznakami oraz umundurowaniem żołnierzy. Wszystkie te rozdziały napisane są wg podobnego schematu. Autor najpierw opisuje ogólną organizację wspomnianych instytucji, dowództw, rodzajów wojsk czy służb, a następnie wymienia istniejące $\mathrm{w}$ ich ramach poszczególne związki taktyczne lub oddziały, przedstawiając syntetycznie ich dzieje, strukturę, liczebność i kadrę dowódczą. W ten sposób powstał szczegółowy, encyklopedyczny zarys wszystkich zorganizowanych przez władze URL w 1920 r. instytucji i formacji wojskowych.

Cennym uzupełnieniem książki A. Rukkasa jest trzynaście szczegółowych i czytelnych schematów wyjaśniających strukturę organizacyjną poszczególnych organów dowódczych, związków taktycznych, oddziałów i pododdziałów. Praca zawiera też kilka tabel przestawiających wykazy wyposażenia, stany liczebne, a także systemy stopni wojskowych stosowane w Armii URL. 
Bardzo interesujący jest zawarty w publikacji A. Rukkasa materiał ikonograficzny. Oprócz czterostronicowej, kolorowej wkładki prezentującej elementy umundurowania ukraińskich żołnierzy, opracowanie zawiera ok. 200 czarno-białych, często unikalnych, fotografii. Niestety, autor nie podał źródła pochodzenia większości tych zdjęć. Omawianą książkę uzupełnia wykaz użytych skrótów oraz obszerny indeks osób. Zastanawia fakt, że autor zrezygnował z zestawienia bibliografii. Ten istotny element aparatu naukowego pracy z pewnością wzbogaciłby omawiane opracowanie.

Andrij Rukkas podjął się bardzo trudnego zadania. Zrealizowanie założonego celu przy rozproszonym materiale źródłowym wymagało od niego starannej i żmudnej kwerendy archiwalnej. Moim zdaniem przedsięwzięcie autora zakończyło się sukcesem. Czytelnik otrzymał cenną publikację zawierającą uporządkowane i szczegółowe informacje o organizacji, strukturze, liczebności, kadrze dowódczej, a także umundurowaniu i wyposażeniu Armii URL w 1920 r. Opracowanie adresowane jest do wszystkich osób interesujących się ukraińską historią wojskową, ale wydaje się, że szczególnie ważne jest dla badaczy zajmujących się innymi niż czysto wojskowe kwestiami sojuszu polsko-ukraińskiego z $1920 \mathrm{r}$. Skorzystanie z wiedzy zawartej w książce A. Rukkasa zaoszczędzi im bowiem często uciążliwej kwerendy archiwalnej, a rzetelność omawianego opracowania gwarantuje uniknięcie licznych błędów powielanych dotąd zarówno w ukraińskiej, jak i polskiej historiografii. 